\section{References}

1 Barth PG, Ryan MM, Webster RI et al. Rhabdomyolysis in pontocerebellar hypoplasia type 2 (PCH-2). Neuromuscul Disord 2008; 18: 52-58.

2 Namavar Y, Barth PG, Poll-The BT et al. Classification, diagnosis and potential mechanisms in pontocerebellar hypoplasia. Orphanet J Rare Dis 2011; 6: 50.
3 Maras-Genc H, Uyur-Yalcin E, Rosti RO et al. TSEN54 gene-related pontocerebellar hypoplasia type 2 presenting with exaggerated startle response: report of two cases in a family. Turk J Pediatr 2015; 57: 286289.
4 Buchan JC, Norris J, Kuper H. Accuracy of referencing in the ophthalmic literature. $\mathrm{Am} \mathrm{J}$ Ophthalmol 2005; 140: 1146-1148.

5 McLellan MF, Case LD, Barnett MC. Trust, but verify. The accuracy of references in four anesthesia journals. Anesthesiology 1992; 77: 185-188.

\title{
Comment on 'Utility of screening questionnaire, obesity, neck circumference, and sleep polysomnography to predict sleep-disordered breathing in children and adolescents
}

SIR - We read with interest the article by Raman et al. (1) which describes the utility of a screening questionnaire, together with anthropometric measurements of obesity and neck circumference to predict sleep-disordered breathing in children and adolescents. While we fully acknowledge that this study is a timely and important addition to the pediatric literature, we must respectfully disagree with their characterization of the STBUR (Snoring, Trouble Breathing, Un-Refreshed) tool which we had previously developed as a risk assessment tool for identifying children with sleep-disorded-breathingrelated perioperative respiratory adverse events (PRAE) (2). In their paper, the authors incorrectly state that the five items that comprise the STBUR tool were arbitrarily selected. However, as clearly described in our paper, we had conducted a factor analysis of items from the Sleep-Related Breathing Disorder subscale of the Pediatric Sleep Questionnaire (3) to identify which factors were the most predictive of perioperative respiratory adverse events. From this analysis, five factors emerged which comprise the STBUR scale. As such, selection of the STBUR items was statistically not arbitrarily based.

\section{Ethics approval}

This letter did not require ethical approval.

\section{Funding}

The study received no external funding.

\section{Conflict of interest}

The authors report no conflict of interest.

Alan R. Tait ${ }^{1}$, Terri Voepel-Lewis ${ }^{1}$, Robert Christensen ${ }^{1} \&$ Louise M. O'Brien ${ }^{2,3,4}$

${ }^{1}$ Department of Anesthesiology, University of Michigan Health System, Ann Arbor, MI, USA

${ }^{2}$ Department of Neurology, University of Michigan Health System, Ann Arbor, MI, USA

${ }^{3}$ Department of Oral/Maxillofacial Surgery, University of Michigan Health System, Ann Arbor, MI, USA

${ }^{4}$ The Michael S. Aldridge Sleep Disorders Center, University of Michigan Health System, Ann Arbor, MI, USA Email: atait@umich.edu doi:10.1111/pan.12952

\section{References}

1 Raman V, Splaingard M, Tumin D et al. Utility of screening questionnaire, obesity, neck circumference, and sleep polysomnography to predict sleep-disordered breathing in children and adolescents. Pediatr Anesth 2016; 26: 655664.
2 Tait AR, Voepel-Lewis T, Christensen R et al. The STBUR questionnaire for predicting perioperative respiratory adverse events in children at risk for sleep-disordered breathing. Pediatr Anesth 2013; 23: 510-516.
3 Chervin R, Hedger K, Dillon J et al. Pediatric sleep questionnaire (PSQ): validity and reliability of scales for sleep-disordered breathing, snoring, sleepiness, and behavioral problems. Sleep Med 2000; 1: 21-32. 